\title{
ANALISIS PENGARUH KEBIJAKAN HUTANG, KEBIJAKAN DIVIDEN, DAN PERTUMBUHAN PERUSAHAAN TERHADAP NILAI PERUSAHAAN DENGAN PROFITABILITAS SEBAGAI VARIABEL INTERVENING PADA PERUSAHAAN PEMBIAYAAN YANG TERDAFTAR DI BURSA EFEK INDONESIA
}

\author{
Febriani Florentin Sinaga 1, Matrodji Mustafa 2 \\ 1,2Fakultas Ekonomi dan Bisnis, Universitas Mercu Buana, Jakarta
}

\begin{abstract}
Abstrak $\mid$ Penelitian ini bertujuan untuk menganalisis pengaruh kebijakan hutang, kebijakan dividen, dan pertumbuhan perusahaan terhadap nilai perusahaan dengan profitabilitas sebagai variabel intervening pada perusahaan pembiayaan. Populasi penelitian ini adalah seluruh perusahaan pembiayaan yang terdaftar di Bursa Efek Indonesia (BEI) pada tahun 2015 dan 2016. Menggunakan teknik purposive sampling, dari jumlah populasi sebanyak 15 perusahaan pembiayaan, hanya 12 perusahaan yang digunakan sebagai sampel penelitian. Data yang digunakan dalam penelitian adalah data keuangan yang tersedia di website BEI. Data dianalisis menggunakan analisis jalur dengan dua persamaan yaitu faktor-faktor yang mempengaruhi nilai perusahaan dan faktor-faktor yang mempengaruhi profitabilitas. Hasil penelitian menunjukkan bahwa kebijakan hutang, kebijakan dividen, pertumbuhan perusahaan, dan profitabiltas tidak berpengaruh secara signifikan terhadap nilai perusahaan. Sementara itu, diantara kebijakan hutang, kebijakan dividen, dan pertumbuhan perusahaan, hanya kebijakan dividen yang berpengaruh signifikan terhadap profitabilitas.
\end{abstract}

Kata Kunci : $\quad$ Kebijakan hutang, kebijakan dividen, pertumbuhan perusahaan, profitabilitas

\begin{abstract}
This study aims to analyze the effect of debt policy, dividend policy, and company growth on company value, with profitability as the intervening variable, in the finance companies listed on the Indonesia Stock Exchange (IDX). The population of this study was all finance companies listed on IDX for the period of 2015 and 2016. The purposive sampling method was used in this study with the sample consisted of 12 finance companies. Data used were financial data sourced from the website of IDX. Data were analyzed using path analysis with two equations, i.e., the factors affecting company value and the factors affecting company profitability. Results of the study showed that debt policy, dividend policy, company growth, and profitability have no significant effect on company value. This study also found that debt policy and company growth have no significant effect on profitability, while dividend policy significantly affects profitability.
\end{abstract}

Keywords : Debt policy, dividend policy, company growth, profitability

Fakultas Ekonomi dan Bisnis Universitas Mercu Buana Jakarta E-mail : febri_ffnaga@gmail.com 


\section{Pendahuluan}

Dengan perkembangan yang terjadi saat ini, banyak investor yang membutuhkan dana untuk melakukan investasi. Lembaga keuangan hadir untuk menyediakan jasa sebagai perantara antara pemilik modal dan pasar uang.

Kehadiran lembaga keuangan inilah yang memfasilitasi arus peredaran uang dalam perekonomian, dimana uang dari investor dikumpulkan dalam bentuk tabungan, sehingga risiko dari para investor ini beralih pada lembaga keuangan yang kemudian menyalurkan dana tersebut dalam bentuk pinjaman hutang kepada yang membutuhkan.

Investor juga akan menilai kinerja mendatang perusahaan. Dengan adanya prospek yang menjanjikan di masa yang akan datang, maka investor akan semakin tertarik menanamkan modalnya. Harapan para investor, perusahaan dapat memberikan kemakmuran bagi investor melalui investasi yang dilakukannya (Dewi dan Wirajaya, 2013).

Semakin tinggi tingkat kemakmuran pemilik perusahaan maka akan meningkatkan nilai perusahaan (Mayogi dan Fidiana, 2016). Nilai perusahaan ini menjadi sangat penting karena mencerminkan kinerja perusahaan yang dapat memberikan pengaruh terhadap persepsi investor terhadap perusahaan.

Nilai perusahaan merupakan nilai pasar dari suatu ekuitas perusahaan ditambah nilai pasar hutang. Dengan demikian, penambahan dari jumlah ekuitas perusahaan dengan hutang perusahaan dapat mencerminkan nilai perusahaan (Kusumajaya, 2011; Dewi dan Wirajaya, 2013). Tabel berikut merupakan nilai industri keuangan dengan menggunakan PBV sebagai indikator.
Tabel 1. PBV Financial Intitution yang Terdaftar di Bursa Efek Indonesia

\begin{tabular}{llllll}
\hline Financial & $\mathbf{2 0 1 2}$ & $\mathbf{2 0 1 3}$ & $\mathbf{2 0 1 4}$ & $\mathbf{2 0 1 5}$ & $\mathbf{2 0 1 6}$ \\
\hline Bank & 1,81 & 0,96 & 0,62 & 1,45 & 1,35 \\
Finance & $-0,34$ & $-0,28$ & 1,15 & 1,18 & 1,03 \\
Securities & 1,48 & 2,54 & 1,54 & 1,39 & 2,56 \\
Insurance & 0,86 & 1,03 & 1,17 & 1,54 & 1,94 \\
Other & 2,36 & 2,83 & 1,3 & 1,59 & 1,61 \\
Total & $\mathbf{6 , 1 7}$ & $\mathbf{7 , 0 8}$ & $\mathbf{5 , 7 8}$ & $\mathbf{7 , 1 5}$ & $\mathbf{8 , 4 9}$ \\
\hline
\end{tabular}

Sumber : www.idx.co.id

Tabel 1 memberikan indikasi mula-mula bahwa lembaga keuangan mempunyai tren yang menarik. Pada tahun 2012 dan 2013 prosentase PBV pada finance company berada pada posisi yang kurang baik dibandingkan lembaga keuangan lainnya. Namun pada tahun 2014, PBV pada finance company mengalami kenaikan menjadi 1,15. Menurut Gordon dan Lintner (1956), perhitungan rasio PBV dilakukan dengan menurunkan dari metode valuasi diskonto dividen dengan faktor pertumbuhannya dan dikenal dengan Gordon Growth Model.

Terdapat beberapa faktor yang mempengaruhi nilai perusahaan. Faktor yang pertama adalah kebijakan hutang. Menurut Mogdiliani dan Miller, nilai perusahaan ditentukan oleh struktur modal. Kebijakan hutang sangat sensitif terhadap perubahan nilai perusahaan. Semakin tinggi proporsi hutang maka semakin tinggi pula harga saham.

Herawati (2013) mengungkapkan bahwa pada prinsipnya setiap perusahaan membutuhkan dana dan pemenuhan dana tersebut dapat berasal dari sumber intern ataupun ekstern. Kebijakan hutang perlu dikelola karena penggunaan hutang yang tinggi akan meningkatkan nilai perusahaan karena penggunaan hutang dapat menghemat pajak. Penggunaan hutang yang tinggi juga dapat menurunkan nilai perusahaan karena adanya kemungkinan timbulnya biaya kepailitan dan biaya keagenan. Kebijakan hutang itu sendiri diukur dengan Debt to Equity Ratio (DER).

Tinggi rendahnya hutang yang digunakan tidak mempengaruhi harga saham pasar namun karena kondisi pasar, investor juga tidak hanya memperhatikan dari hutang yang digunakan namun cenderung lebih memperhatikan bagaimana manajer mengolah 
kebijakan hutang dengan efektif dan efisien pada perusahaan sehingga menghasilkan nilai perusahaan yang baik.

Faktor-faktor lain yang menentukan PBV telah dikaji oleh peneliti sebelumnya yang meliputi kebijakan dividen, pertumbuhan perusahaan dan profitabilitas. Berdasarkan kamus besar Bahasa Indonesia, dividen berarti sejumlah uang sebagai hasil keuntungan yang dibayarkan kepada pemegang saham (dalam suatu Perseroan). Apabila saldo laba didisitribusikan kepada pemegang saham maka saldo laba akan berkurang sebesar nilai yang didistribusikan tersebut.

Faktor yang ketiga adalah pertumbuhan perusahaan (growth). Pertumbuhan (growth) adalah seberapa jauh perusahaan menempatkan diri dalam sistem ekonomi secara keseluruhan atau sistem ekonomi untuk industri yang sama (Machfoeds dalam Safitri dan Suwitho, 2015). Pertumbuhan perusahaan merupakan kemampuan perusahaan untuk meningkatkan size yang dapat dipengaruhi oleh beberapa faktor, yaitu faktor eksternal, internal, dan pengaruh iklim industri (Herawati, 2013). Pertumbuhan perusahaan yang cepat akan mengakibatkan besarnya kebutuhan dana bagi perusahaan untuk ekspansi. Semakin besar kebutuhan untuk pembiayaan mendatang maka semakin besar keinginan perusahaan untuk menahan laba. Jika investasi dilakukan dengan tepat, maka pertumbuhan perusahaan akan mendatangkan laba dimasa depan.

Faktor yang keempat adalah Profitabilitas. Profitabilitas merupakan kemampuan laba yang dihasilkan oleh perusahaan. Manajer keuangan yang menggunakan pecking order theory dengan laba ditahan sebagai pilihan pertama dalam pemenuhan kebutuhan dana dan hutang sebagai pilihan kedua serta penerbitan saham sebagai pilihan ketiga akan selalu memperbesar profitabilitas untuk meningkatkan laba. Profitabilitas sangat diperhatikan oleh calon investor maupun pemegang saham karena berkaitan dengan harga saham yang akan diterima (Mayogi, 2016).

Salah satu ukuran profitabilitas yang digunakan adalah Return On Equity (ROE) yang menjadi tolak ukur kemampuan perusahaan dalam menghasilkan laba dengan total modal sendiri yang digunakan. Dalam penelitian ini, yang digunakan untuk mengukur profitabilitas perusahaan adalah ROE, karena ROE mengukur kemampuan perusahaan memperoleh laba yang tersedia bagi para pemegang saham dalam bentuk penyertaan modal sendiri yang ditanamkan oleh pemegang saham.

Dalam perkembangannya, keberadaan lembaga perbankan tidak mencukupi kebutuhan akan dana yang sangat dibutuhkan oleh masyarakat. Oleh karena itu diperlukan adanya alternatif pembiayaan lainnya selain bank. Adanya alternatif pembiayaan lainnya dimaksud dibutuhkan mengingat akses untuk mendapatkan dana dari bank sangat terbatas. Mengantisipasi hal tersebut, maka pemerintah pada tahun 1988, membuka peluang bagi berbagai badan usaha untuk melakukan kegiatan-kegiatan pembiayaan sebagai alternatif lain untuk menyediakan dana guna menunjang pertumbuhan perekonomian Indonesia. Kegiatan tersebut dilakukan oleh suatu lembaga yang disebut lembaga pembiayaan.

Berikut adalah daftar perusahaan pembiayaan yang terdaftar di BEI disajikan dengan PBV sebagai indikator nilai perusahaan.

Tabel 2. PBV Finance Company yang Terdaftar di Bursa Efek Indonesia

\begin{tabular}{|c|c|c|c|c|c|}
\hline $\begin{array}{l}\text { Finance } \\
\text { Company }\end{array}$ & 2012 & 2013 & 2014 & 2015 & 2016 \\
\hline $\begin{array}{l}\text { Adira } \\
\text { Dinamika } \\
\text { Finance Tbk. }\end{array}$ & 2,87 & 1,95 & 1,35 & 1,77 & 0,8 \\
\hline $\begin{array}{l}\text { Amstelco } \\
\text { Indonesia }\end{array}$ & $-20,9$ & $-16,8$ & 0 & 0 & 0 \\
\hline $\begin{array}{l}\text { Batavia } \\
\text { Prosperindo } \\
\text { Finance Tbk. }\end{array}$ & 1,31 & 0,96 & 1,9 & 2,79 & 1,9 \\
\hline $\begin{array}{l}\text { BFI Finance } \\
\text { Indonesia }\end{array}$ & 1,83 & 1,08 & 1,12 & 1,08 & 1,09 \\
\hline $\begin{array}{l}\text { Buana } \\
\text { Finance Tbk. }\end{array}$ & 0,78 & 1,15 & 1,16 & 1,59 & 1,63 \\
\hline $\begin{array}{l}\text { Clipan } \\
\text { Finance }\end{array}$ & 0,75 & 0,62 & 0,55 & 0,54 & 0,3 \\
\hline $\begin{array}{l}\text { Danasupra } \\
\text { erapacific }\end{array}$ & 0,88 & 1,52 & 1,71 & 1,67 & 1,85 \\
\hline $\begin{array}{l}\text { HD Finance } \\
\text { Tbk. }\end{array}$ & 1,7 & 1,63 & 1,33 & - & - \\
\hline $\begin{array}{l}\text { Intan } \\
\text { Baruprana }\end{array}$ & - & - & - & 1,67 & 1,13 \\
\hline $\begin{array}{l}\text { Indomobil } \\
\text { multi Jasa }\end{array}$ & - & - & 1,58 & 1,85 & 1,06 \\
\hline
\end{tabular}




\begin{tabular}{lccccc}
\hline \multicolumn{1}{c}{$\begin{array}{c}\text { Finance } \\
\text { Company }\end{array}$} & $\mathbf{2 0 1 2}$ & $\mathbf{2 0 1 3}$ & $\mathbf{2 0 1 4}$ & $\mathbf{2 0 1 5}$ & $\mathbf{2 0 1 6}$ \\
\hline $\begin{array}{l}\text { Mandala } \\
\text { Multifinance }\end{array}$ & 1,61 & 0,89 & 0,81 & 0,65 & 0,38 \\
$\begin{array}{l}\text { Magna } \\
\text { Finance Tbk. }\end{array}$ & - & - & - & 0,93 & 0,72 \\
$\begin{array}{l}\text { Radana } \\
\text { Bhaskara }\end{array}$ & - & - & - & 1,04 & 0,85 \\
$\begin{array}{l}\text { Finance Tbk. } \\
\begin{array}{l}\text { Tifa Finance } \\
\text { Tbk }\end{array}\end{array}$ & 1,05 & 1,08 & 1,24 & 0,05 & 0,51 \\
$\begin{array}{l}\text { Trust Finance } \\
\text { Indonesia }\end{array}$ & 1,9 & 1,09 & 0,85 & 0,79 & 0,71 \\
$\begin{array}{l}\text { Verena multi } \\
\text { Finance Tbk. }\end{array}$ & 0,71 & 0,47 & 0,36 & 0,29 & 0,56 \\
$\begin{array}{l}\text { Wahana } \\
\text { ottomitra } \\
\text { multiartha }\end{array}$ & 1,15 & 0,83 & 0,92 & 0,75 & 0,37 \\
$\quad$ Total & $\mathbf{0 , 3 4}$ & $\mathbf{- 0 , 2 8}$ & $\mathbf{1 , 1 5}$ & $\mathbf{1 , 1 8}$ & $\mathbf{1 , 0 3}$ \\
\hline
\end{tabular}

Sumber : www.idx.co.id

Perusahaan pembiayaan yang bergerak dalam bidang jasa pemenuhan pembiayaan kebutuhan masyarakat saat ini dianggap memiliki rate yang cukup tinggi, dibandingkan dengan perbankan. Kendati demikian, perusahaan pembiayaan dapat tetap tumbuh.

\section{Metodologi}

\section{Jenis Penelitian}

Berdasarkan sifatnya, jenis data yang digunakan dalam penelitian ini adalah data kuantitatif. Data kuantitatif adalah data berupa angka hasil dari suatu pengukuran, observasi, dan pembilang yang dapat dianalisis menggunakan metode statistik, untuk memperoleh kecenderungan, prediksi hubungan antarvariabel, komparasi hasil dengan perbandingan kelompok, sehingga dapat ditampilkan dalam bentuk data-data statistik (Riadi, 2016 : 48).

Objek dalam penelitian adalah perusahaan pembiayaan dengan alasan bahwa perusahaan pembiayaan adalah perusahaan keuangan non-bank yang saat ini cukup berkembang pesat di Indonesia. Data yang diperlukan dalam penelitian ini yaitu kebijakan hutang, kebijakan dividen, total aset, profitabilitas dan nilai perusahaan. Dengan demikian, sumber data yang digunakan adalah data sekunder. Data sekunder tersebut berasal dari laporan tahunan perusahaan pembiayaan yang terdaftar di Bursa Efek Indonesia (BEI) pada tahun 2015 dan 2016 dalam situs resmi BEI yaitu www.idx.co.id.

\section{Populasi dan Sampel Penelitian}

Populasi yang digunakan adalah seluruh perusahaan pembiayaan yang terdaftar di BEI selama kurun waktu penelitian tahun 2015 dan 2016. Karakteristik populasi harus mewakili sampel, artinya ciri atau keadaan populasi harus tergambarkan dalam sampel (Kadir, 2016:119). Sampel diperoleh dengan menggunakan purposive sampling, dimana sampel digunakan apabila memenuhi kriteria yaitu perusahaan pembiayaan yang terdaftar di BEI tahun 2015 dan 2016.

Tabel 3. Kriteria Pengambilan Sampel

\begin{tabular}{lll}
\hline No & Keterangan & Jumlah \\
\hline 1 & $\begin{array}{l}\text { Jumlah perusahaan } \\
\text { pembiayaan }\end{array}$ & 15 \\
2 & $\begin{array}{l}\text { Perusahaan yang tidak } \\
\text { memiliki laporan lengkap }\end{array}$ & $(3)$ \\
\hline & $\begin{array}{l}\text { Jumlah perusahaan yang } \\
\text { menjadi sampel }\end{array}$ & 12 \\
\hline
\end{tabular}

Sumber : www.idx.co.id

Berdasarkan data perusahaan pembiayaan yang terdaftar di BEI diketahui bahwa jumlah perusahaan pembiayaan pada periode 2015 dan 2016 sebanyak 15 perusahaan. Dari jumlah tersebut, sebanyak 12 sampel perusahaan yang memenuhi kriteria yang diajukan dalam penelitian ini dan dapat dilihat dalam tabel berikut:

Tabel 4. Daftar Sampel Penelitian

\begin{tabular}{cl}
\hline No & \multicolumn{1}{c}{ Finance Company } \\
\hline 1 & Adira Dinamika multi Finance Tbk. \\
2 & Batavia Prosperindo Finance Tbk. \\
3 & BFI Finance Indonesia Tbk. \\
4 & Buana Finance Tbk. \\
5 & Clipan Finance Indonesia Tbk. \\
6 & Danasupra Erapacific Tbk. \\
7 & HD Finance Tbk. (Radana Bhaskara \\
8 & Finance, Tbk.) \\
9 & Mandala Multifinance Tbk. \\
10 & Trust Finance Tbk \\
11 & Verenance Multi Finance Tbk. Tbk. \\
12 & Wahana Ottomitra multiartha Tbk. \\
\hline
\end{tabular}

Sumber: www.idx.co.id

Secara keseluruhan, berdasarkan rumusan masalah dan hipotesis penelitian terlihat bahwa hubungan antara variabel yang menjadi fokus penelitian ini menunjukkan 
hubungan yang melibatkan variabel endogen, variabel eksogen, dan variabel intervening. Hipotesis dalam penelitian ini akan diuji dengan menggunakan analisis jalur (path analysis). Analisis data menggunakan SPSS sebagai alat untuk analisa.

\section{Analisis Jalur (Path Analysis)}

Analisis jalur (Path Analysis) merupakan teknik analisis yang digunakan untuk mempelajari hubungan kausal antara variabel bebas dan variabel tak bebas. Hubungan kausal disusun dalam bentuk model hipotetik yang didasarkan pada substansi keilmuwan yaitu landasan teoritis dan/atau pengalaman peneliti. Pengujian hipotesis menggunakan teknik analisis jalur sangat bergantung pada kuat lemahnya teori yang mendasari model hipotetik yang disusun (Kadir, 2016:240).

Diagram Jalur dan Koefisien Jalur

Menurut Kadir (2016 : 242), besarnya pengaruh langsung variabel eksogen terhadap variabel endogen dinyatakan dengan koefisien jalur. Notasi atau simbol dari koefisien jalur dituliskan sebagai pij di mana $i$ menyatakan akibat (endogen) dan $j$ menyatakan sebab (eksogen). Sebagai contoh dalam penelitian ini notasi p41 dimaknai sebagai pengaruh langsung variabel $\mathrm{X}_{1}$ terhadap variabel $\mathrm{X}_{4}$ begitupula notasi py berarti pengaruh langsung variabel $\mathrm{X}$ terhadap variabel $\mathrm{Y}$. Koefisien jalur ekivalen dengan koefisien regresi sebagai estimator terhadap koefisien beta $(\beta)$ untuk skor baku. Koefisien-koefisien ini biasanya dicantumkan pada diagram jalur tepat pada setiap garis jalur yang nilainya dalam bentuk numerik. Dengan demikian, untuk mengestimasi koefisien jalur, misalnya variabel eksogen $\left(X_{1}\right),\left(X_{2}\right),\left(X_{3}\right)$ terhadap variabel intervening $\left(\mathrm{X}_{4}\right)$ dapat diestimasi dengan kolerasi sederhana $(\mathrm{p} 41)=\mathrm{bx} 1 \mathrm{x} 4$; $(\mathrm{p} 42)=\mathrm{bx} 2 \times 4$; dan $(\mathrm{p} 43)=\mathrm{bx} 3 \times 4$, . Jika variabel endogen $(\mathrm{Y})$ dipengaruhi oleh variabel eksogen $\left(\mathrm{X}_{1}\right),(\mathrm{X} 2)$, dan $\left(\mathrm{X}_{3}\right)$ maka koefisien jalur $X_{1}$ terhadap $Y$ selanjutnya $X_{2}$ terhadap $\mathrm{Y}$ dan $\mathrm{X}_{3}$ terhadap $\mathrm{Y}$ diestimasi oleh besarnya koefisien bij dalam regresi skor baku, yaitu py $1=$ bx1y; py $2=b x 2 y$; dan py3 = bx3y.
Model diagram jalur yang digunakan dalam penelitian ini disertai persamaan strukturalnya disajikan sebagai berikut:

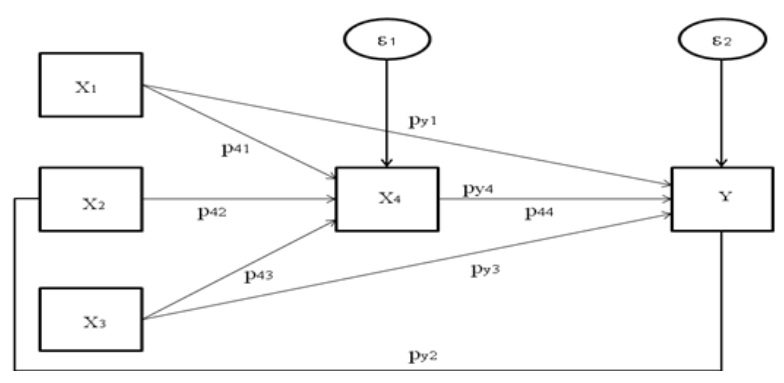

Gambar 1. Diagram Jalur

Persamaan struktural untuk diagram di atas adalah sebagai berikut:

$X_{4}=p_{41} X_{1}+p_{42} X_{2}+p_{43} X_{3}+\varepsilon_{1} \ldots \ldots \ldots \ldots \cdots \cdots \cdots \cdots \cdots \cdots \cdots$

$Y=p_{y 1} X_{1}+p_{y 2} X_{2}+p_{y 3} X_{3}+p_{j 4} X_{4}+\varepsilon_{2} \ldots \ldots \ldots \ldots \ldots \ldots$

\section{Hasil dan Pembahasan}

Pengujian hipotesis menunjukkan seberapa jauh pengaruh satu variabel bebas secara individual dalam menerangkan variabelvariabel tersebut.

Tabel 5. Ringkasan hasil pengujian hipotesis dengan SPSS dengan Data DER, DPR, Asset Growth, ROE dan PBV tahun 2015

\begin{tabular}{|c|c|c|c|c|}
\hline $\begin{array}{l}\text { Pengaruh } \\
\text { langsung } \\
\text { antar } \\
\text { variabel }\end{array}$ & $\begin{array}{l}\text { Koefisi } \\
\text { en jalur } \\
\left(p_{i j}\right)\end{array}$ & thitung & $\begin{array}{l}\text { p- } \\
\text { value }\end{array}$ & Simpulan \\
\hline $\mathrm{X}_{1} \rightarrow \mathrm{X}_{4}$ & 0,014 & 0,049 & 0,481 & $\begin{array}{c}\text { Tidak } \\
\text { Signifikan }\end{array}$ \\
\hline $\mathrm{X}_{2} \rightarrow \mathrm{X}_{4}$ & 0,600 & 2,172 & 0,019 & Signifikan \\
\hline $\mathrm{X}_{3} \rightarrow \mathrm{X}_{4}$ & $-0,034$ & 2,369 & 0,454 & $\begin{array}{c}\text { Tidak } \\
\text { Signifikan }\end{array}$ \\
\hline $\mathrm{X}_{1} \rightarrow \mathrm{Y}$ & $-0,283$ & $\begin{array}{l}- \\
0,988\end{array}$ & 0,176 & $\begin{array}{c}\text { Tidak } \\
\text { Signifikan }\end{array}$ \\
\hline $\mathrm{X}_{2} \rightarrow \mathrm{Y}$ & 0,353 & 1,177 & 0,135 & $\begin{array}{c}\text { Tidak } \\
\text { Signifikan }\end{array}$ \\
\hline $\mathrm{X}_{3} \rightarrow \mathrm{Y}$ & $-0,397$ & $\begin{array}{l}- \\
1,368\end{array}$ & 0,101 & $\begin{array}{c}\text { Tidak } \\
\text { Signifikan }\end{array}$ \\
\hline $\mathrm{X}_{4} \rightarrow \mathrm{Y}$ & 0,138 & 0,365 & 0,363 & $\begin{array}{c}\text { Tidak } \\
\text { Signifikan }\end{array}$ \\
\hline
\end{tabular}

Sumber: Output SPSS (diolah) 
Dengan demikian, berdasarkan hasil pengujian hipotesis dengan aplikasi SPSS, model kausal empiris $\mathrm{X}_{1}, \mathrm{X}_{2}, \mathrm{X}_{3}$, dan $\mathrm{X}_{4}$ dengan $\mathrm{Y}$, divisualkan adalah sebagai berikut:

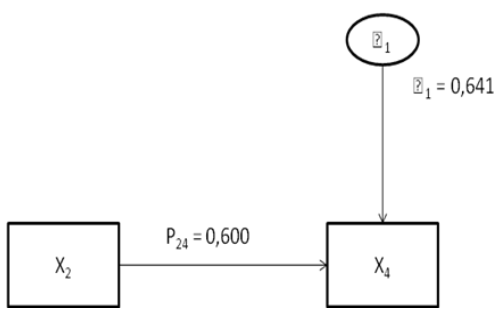

\section{Gambar 2. Hasil Koefisien Diagram Jalur} Sumber: data diolah

Dalam menguji validitas model di dalam analisis jalur digunakan koefisien determinasi total, diukur dengan:

$$
\begin{aligned}
P e_{1} & =\sqrt{1-R^{2}} \\
= & \sqrt{1-0,359^{2}} \\
= & 0,641 \\
P e_{2} & =\sqrt{1-R^{2}} \\
& =\sqrt{1-0,00^{2}} \\
& =1 \\
& =\frac{1-R_{m}{ }^{2}}{1-R_{e}{ }^{2}}
\end{aligned}
$$

dengan koefisien determinasi untuk model 1 masing-masing pada struktural 1 dan struktural 2, yaitu:

$R_{m}{ }^{2}=1-(1-1,360)(1-0,158)$

$R_{e}^{2}=1-(1-1,359)(1-0,00)$

$Q=\frac{0,46112}{0,359} \quad=1,2845$

Dengan ukuran sampel (n) $=12$, dan banyaknya koefisien jalur yang tidak signifikan (d) $=1$, maka statistik uji Chi-Square dengan $\mathrm{W}=-(\mathrm{n}-\mathrm{d}) \ln \mathrm{Q}=-(12-1) \ln (1.2845)=$ -2,754. Dari tabel Chi-Square dengan $\mathrm{db}=\mathrm{d}=1$ pada taraf signifikansi $\alpha=0.05$ di dapat harga $\chi^{2}$ tab $=\chi^{2}(0,05 ; 1)=3,84$. Karena $\mathrm{W}=-2,754<3,84$ atau $\mathrm{H}_{0}$ diterima. Dengan demikian, model yang diperoleh adalah sesuai atau cocok (model fit) dengan data.

Dalam pasar modal yang efisien, harga suatu saham mencerminkan informasi yang memiliki hubungan dengan aktivitas manajemen dan prospek perusahaan di masa yang akan datang, dan ketika muncul informasi baru tentang perusahaan tersebut maka harga saham akan berubah untuk mencerminkan adanya informasi baru tersebut.

Capital market yang efficient adalah capital market dimana harga-harga surat berharga (security prices) akan disesuaikan secara cepat dengan masuknya informasi baru. Informasi tentang saham misalnya tercermin dalam harga saham. Pada efficient capital market, semua informasi mengenai saham tersebut sudah tercermin didalam harga. Menurut Fama (1970), terdapat tiga kategori efficient capital market berdasarkan jenis informasi yang membuat harga saham berubah, yaitu efisiensi pasar bentuk lemah, efisiensi pasar bentuk setengah kuat, dan efisiensi pasar bentuk kuat.

Efisiensi pasar bentuk Lemah mempunyai hipotesa bahwa semua informasi berkenaan dengan pergerakan harga-harga saham yang lalu sudah tercermin pada harga sekarang. Past security-market (historical public) information didalamnya termasuk historical sequence of price, rates of return, tradingvolume data dan informasi lainnya pada pasar saham tersebut. Teori ini hanya meliputi data historis mengenai harga dan volume.

Efisiensi pasar bentuk setengah kuat mempunyai hipotesa bahwa semua informasi yang sudah diterima oleh publik (all publicly available information) mengenai prospek dan kinerja perusahaan harus sudah tercermin didalam harga saham. Disini harga saham tidak hanya mencerminkan past prices tetapi juga semua informasi yang masuk ke publik. Disini harga akan disesuaikan dengan masuknya informasi ke publik seperti berita pendapatan perusahaan pada semester atau kuartal yang baru lewat, rencana merger perusahaan, dan lain-lain. 
Efisiensi pasar bentuk kuat mempunyai hipotesa bahwa semua informasi yang relevan baik public information maupun inside (privately held) information sudah tercermin didalam harga saham (harga saham saat ini telah mencerminkan semua public and private information yang relevan).

Selain itu, Modigliani dan Miller dengan $M M$ theory berpendapat bahwa struktur capital yang dipilih perusahaan tidak mempunyai pengaruh terhadap nilai perusahaan (Marharetha dan Ramadhan, 2010). Jika terdapat pajak atas laba maka menurut MM, nilai perusahaan dengan hutang (levered firm) sama dengan nilai perusahaan tanpa hutang (unlevered) ditambah nilai sekarang dari penghematan pajak (interest tax shield). Penggunaan hutang menyebabkan nilai perusahaan meningkat artinya semakin banyak penggunaan hutang maka semakin tinggi nilai perusahaan. The cost of equity meningkat dengan penggunaan leverage. WACC (weighted average cost of capital) akan mengecil dengan meningkatnya leverage.

Teori lain, Trade-off theory memperhitungkan keuntungan penggunaan hutang berupa bertambahnya nilai perusahaan dari penghematan pajak dan biaya yang tercipta berupa bunga yang lebih tinggi dan bankruptcy serta agency cost. Agency cost timbul karena penggunaan hutang membatasi gerak manajemen dalam mengelola perusahaan (Harjito, 2011).

Dengan demikian penggunaan hutang sekalipun dapat meningkatkan nilai perusahaan namun ada batasannya. Esensi trade-off theory dalam struktur modal adalah menyeimbangkan manfaat dan pengorbanan yang timbul sebagai akibat penggunaan hutang (Harjito, 2011). Sejauh manfaat lebih besar, tambahan hutang masih diperkenankan. Apabila pengorbanan karena penggunaan hutang sudah lebih besar, maka tambahan hutang sudah tidak diperbolehkan. Trade-off theory telah mempertimbangkan berbagai faktor seperti corporate tax, biaya kebangkrutan, dan personal tax, dalam menjelaskan mengapa suatu perusahaan memilih struktur modal tertentu (Husnan dalam Kusumawijaya, 2011).
Teori perusahaan (theory of the firm) menjelaskan bahwa maksud dan tujuan utama perusahaan adalah untuk memaksimumkan kekayaan atau nilai perusahaan (firm value). Menurut Michell Suharli dalam Hidayati (2010), dalam penilaian perusahaan mengandung unsur proyeksi, asuransi, perkiraan dan judgement. Nilai dari perusahaan bergantung tidak hanya pada kemampuan menghasilkan arus kas, juga bergantung pada karakteristik operasional dan keuangan dari perusahaan yang diambil alih. Beberapa variabel kuantitatif yang sering digunakan untuk memperkirakan nilai perusahaan yaitu nilai buku, nilai appraisal, nilai nilai pasar saham, nilai chop-shop, dan nilai arus kas.

Nilai buku per lembar saham (BV) digunakan untuk mengukur nilai shareholder equity atas setiap saham, dan besarnya nilai BV dihitung dengan cara membagi total shareholder equity dengan jumlah saham yang beredar. Adapun komponen dari share holder equity yaitu agio saham (paid up capital in excess of par value) dan laba ditahan (retained earning).

Nilai appraisal suatu perusahaan dapat diperoleh dari perusahaan appraisal independent. Teknik yang digunakan oleh perusahaan appraisal sangat bergam bagaimanapun nilai ini sering dihubungkan dengan biaya penempatan. Metode analisis ini sering tidak mencukupi dengan sendirinya karena nilai aktiva individual mempunyai hubungan yang kecil dengan kemampuan perusahaan secara keseluruhan dalam kegunaan dalam menghasilkan earnings dan kemudian nilai going concern dari suatu perusahaan. Bagaimanapun nilai appraisal dari suatu perusahaan akan bermanfaat sewaktu digunakan dalam penghubungan dengan metode penilaian yang lain.

Nilai pasar saham sebagaimana dinyatakan dalam kuotasi pasar modal adalah pendekatan lain untuk memperkirakan nilai bersih dari suatu bisnis. Apabila saham didaftarkan dalam bursa sekuritas utama dan secara luas diperdagangkan, sebuah nilai pendekatan dapat dibangun berdasarkan nilai pasar. Pendekatan nilai pasar adalah salah satu yang paling sering dipergunakan dalam menilai perusahaan besar. Bagaimanapun nilai ini 
dapat berubah secara cepat. Faktor analisis berkompetisi dengan pengaruh spekulatif murni dan berhubungan dengan sentimen masyarakat dan keputusan pribadi.

Pendekatan "Chop-Shop" untuk valuasi pertama kali diperkenalkan oleh Dean Lebaron dan Lawrence Speidell of Batterymarch Financial Management. Secara khusus, ia menekankan untuk mengidentifikasi perusahaan multi industri yang dibawah nilai akan bernilai lebih apabila dipisahkan menjadi bagian-bagian.

Pendekatan arus kas untuk penilaian dimaksudkan agar dapat mengestimasi arus kas bersih yang tersedia untuk perusahaan yang menawarkan sebagai hasil merger atau akuisisi. Nilai sekarang dari arus kas ini kemudian akan ditentukan dan akan menjadi jumlah maksimum yang harus dibayar oleh perusahaan yang ditargetkan. Pembayaran awal kemudian dapat dikurangi untuk menghitung nilai bersih sekarang dari merger.

\section{Kesimpulan}

Berdasarkan uraian pada bab-bab sebelumnya, maka dapat disimpulkan Kebijakan hutang tidak memiliki pengaruh terhadap nilai perusahaan pembiayaan yang terdaftar di BEI pada tahun 2015 dan 2016. Kebijakan dividen tidak memiliki pengaruh terhadap nilai perusahaan pembiayaan yang terdaftar di BEI pada tahun 2015 dan 2016. Pertumbuhan asset tidak memiliki pengaruh terhadap nilai perusahaan pembiayaan yang terdaftar di BEI pada tahun 2015 dan 2016. Profitabilitas tidak memiliki pengaruh terhadap nilai perusahaan pembiayaan yang terdaftar di BEI pada tahun 2015 dan 2016. Kebijakan hutang tidak memiliki pengaruh terhadap profitabilitas perusahaan pembiayaan yang terdaftar di BEI pada tahun 2015 dan 2016. Kebijakan dividen memiliki pengaruh terhadap profitabilitas perusahaan pembiayaan yang terdaftar di BEI pada tahun 2015, namun ada pengaruh kebijakan dividen terhadap profitabilitas perusahaan pembiayaan yang terdaftar di BEI tahun 2016. Pertumbuhan perusahaan tidak memiliki pengaruh terhadap profitabilitas perusahaan pembiayaan yang terdaftar di BEI pada tahun 2015 dan 2016.

\section{Saran}

Penelitian ini terbtas pada perusahaan pembiayaan semata, kedepan semoga penelitian ini dapat dikembangkan dengan perusahaan keuangan yang lain.

\section{Daftar Referensi}

Dewi, Ayu Sri Mahatma dan Wirajaya, Ary. 2013. Pengaruh Struktur Modal, Profitabilitas dan Ukuran Perusahaan pada Nilai Perusahaan. EJurnal Akuntansi Universitas Udayana. Vol 4 Nomor 2.pp 358-372.

Fama, Eugene, 1970, Efficient Capital Markets - A review of theory and empirical work, Journal of Finance. Vol. 25, No. 2

Harjito, D Agus. 2011. Teori Pecking Order dan Trade-Off dalam Analisis Struktur Modal di Bursa Efek Indonesia. Jurnal Siasat Bisnis. Vol 15 No 2, pp 187-196.

Herawati, Titin. 2013. Pengaruh Kebijakan Dividen, Kebijakan hutang, dan Profitabilitas, terhadap nilai perusahaan. Jurnal Universitas Negeri Padang.

Hidayati, Eva Eko. 2010. Analisis Pengaruh DER, DPR, ROE, dan Size Terhadap PBV Perusahaan Manufaktur yang Listing di BEI Periode 20052007. Tesis. Program Studi Magister Manajemen. Program Pascarsarjana. Universitas Diponegoro. Semarang.

Gordon dan Lintner . 1956, Distributio Of Incomes Of Corporations among dividens, Retained Earnings and Taxes", The American Economic Review 46, 97-113.

Margaretha, Farah dan Ramadhan, Aditya Rizky. 2010. Faktor-Faktor yang Mempengaruhi Struktur Modal Pada Industri Manufaktur di Bursa Efek Indonesia. Jurnal Bisnis dan Akuntansi. Vol 12 No 2 pp 119-130.

Kadir. 2016. Statistika Terapan - Konsep, Contoh, dan Analisis Data dengan Program SPSS/Lisrel dalam Penelitian. Edisi Kedua. Raja Grafindo Persada. Jakarta.

Kusumawijaya, Dewa Kadek Oka. 2011. Pengaruh Struktur Modal dan Pertumbuhan Perusahaan Terhadap Profitabilitas dan Nilai Perusahaan pada Perusahaan Manufaktur di Bursa Efek Indonesia. Tesis. Program Studi Manajemen, Program Pascasarjana. Universitas Udayana. Denpasar.

Mayogi, Dien Gusti, dan Fidiana. 2016. Pengaruh Profitabilitas, Kebijakan Dividen dan 
Kebijakan Hutang Terhadap Nilai Perusahaan. Jurnal Ilmu dan Riset Akuntansi, Vol.5, No.1.

Riadi, Edi. 2016. Aplikasi Lisrel untuk Penelitian Analisis Jalur. Andi. Yogyakarta.

Safitri, Hazlina dan Suwitho. 2015. Pengaruh Size, Growth, dengan Kebijakan Dividen sebagai Variabl Moderating Terhadap Nilai Perusahaan. Jurnal Ilmu dan Riset Manajemen, Vol.4, No.6. 